\title{
Employee Evaluations in the Public Sector: Public Service Motivation, Task, and Citizenship Behaviors
}

\author{
Robert K. Christensen* and Steven W. Whiting**
}

\begin{abstract}
This paper reports the results of a study conducted in fall 2007 among MBA and MPA students. Using electronic surveys and manipulated vignettes, the study explored how public service motivation moderates the relationship between organizational citizenship behaviors, task behaviors, and performance appraisals.
\end{abstract}

Keywords: Public Service Motivation, Organizational Citizenship Behaviors, Performance Appraisals, Human Resource Management

\section{INTRODUCTION}

One of the fundamental endeavors of public service motivation theorists has been to understand how motives within public organizations shape the "quality and content of public outputs" (Perry \& Wise 1990, 369). Perry and Wise $(1990,368)$ defined public service motivation (PSM) as "an individual's predisposition to respond to motives grounded primarily or uniquely in public institutions and organizations." Public service motivation is associated with rational, normative, and affective motives most generally identified by attraction to public policy, commitment to public interest, compas-

* Robert K. Christensen is an Assistant Professor in the Master of Public Administration and Ph.D. in Public Policy programs at University of North Carolina at Charlotte. He received his Ph.D. in public management from Indiana University's School of Public and Environmental Affairs in 2007. His research interests include institutional precursors of public and nonprofit performance, his research focuses on the intersection of public law, policy, and public and nonprofit administration. His work appears in such journals as Administration \& Society and Nonprofit Management and Leadership.

** Steven W. Whiting is an Assistant Professor at the Kelley School of Business, Indiana University. He received his Ph.D. in organization behavior and human resource management from Indiana University in 2006. Dr. Whiting's research focuses on issues of human resource management, especially organization citizenship behaviors. His work has appeared in the Journal of Applied Psychology.

Manuscript received February 2009; out for review February 2009; review completed February 2009; accepted February 2009.

The Korean Journal of Policy Studies, Vol. 23, No. 2, $41-56$ (2009)

(C) 2009 by the GSPA, Seoul National University 
sion, and self-sacrifice (Perry 1996).

PSM theorists have argued that via an attraction-selection-attrition mechanism (Schneider, Goldstein, \& Smith 1995), employees of public organizations will possess higher levels of PSM than employees of private organizations (Wright 2001). That is to say, individuals who are high in PSM will be attracted to, select into, and remain in organizations that primarily serve public interests. While this is a compelling theoretical argument, empirical evidence regarding the impact of public service motivation within organizations is scant at best, and where it exists, results have not consistently confirmed the fundamental hypotheses of public service motivation (Wright 2001). Along these lines Wright $(2007,80)$ recently observed two issues in "the relative infancy" of PSM research, commenting that there is "stronger empirical evidence for [PSM's] existence than its consequences." Without ignoring the former, this research focuses on the latter.

\section{CONSEQUENCES IN PERFORMANCE APPRAISALS}

Researchers in two fields-organizational behavior and industrial-organizational psychology — have focused more intently on the consequences of individual motivations. Perhaps this is because these fields have moved beyond a state of relative infancy. Nevertheless, with respect to motivation in the public sector, can research in organizational behavior or industrial-organizational psychology be directly applied to public organizations with little translation, or do the different work motivations of employees in each type of organization create a need for varying approaches to their management?

The authors view the search for differences in management and makeup between public and private organizations, relative to organizational consequences and activities, to be a question still in need of empirical exploration. As a result, this paper reports the results of research investigating the manner in which PSM might influence the performance appraisal process.

Evaluating subordinates' performance is an important part of a supervisor's job in nearly all organizations. Performance appraisals are a ubiquitous element of organizational life in public and private institutions alike. The research on performance appraisals and the factors that influence supervisory decisions regarding them is voluminous (Bernardin \& Buckley 1981; Cardy \& Dobbins 1994; DeNisi 1996; Feldman 1994). An important theme in this research concerns the varieties of behavior that raters use and weight when making their appraisal decisions. Clearly one important dimension of job performance that is considered in appraisal decisions is task perfor- 
mance or in-role performance. These behaviors involve the completion of tasks or activities that directly contribute to the technical core of the organization (Borman \& Motowidlo 1993), that specifically fulfill written job requirements or descriptions (Williams \& Anderson 1991), or that contribute to the provision of a product or service (Rotundo \& Sackett 2002).

Another important dimension of job performance is termed organizational citizenship behavior (OCB). Organ $(1988,4)$ defined OCB as "individual behavior that is discretionary, not directly or explicitly recognized by the formal reward system, and that in the aggregate promotes the effective functioning of the organization ... the behavior is not an enforceable requirement of the role or the job description ... its omission is not generally understood as punishable." As discussed by Podsakoff et al. (2000), constructs similar to OCB include extra-role behavior, prosocial organizational behavior, organizational spontaneity, and contextual performance.

A growing body of research demonstrates that OCBs are linked to multiple positive outcomes for groups and organizations such as improved quantity and quality of work group performance, customer satisfaction, and profitability (Dunlop \& Lee 2004; Koys 2001; Podsakoff et al. 1997; Podsakoff \& MacKenzie 1994; Walz \& Niehoff 2000). Perhaps as a result of this, related research has demonstrated that managers consider OCBs in making their appraisal decisions. Indeed, findings have converged on the conclusion that both task and citizenship behavior have independent, significant relationships with managerial performance appraisals and related decisions such as reward allocations (Allen \& Rush 1998; Borman \& Motowidlo 1993; Borman et al. 1995; MacKenzie et al. 1991, 1993; Motowidlo \& Van Scotter 1994; Orr et al. 1989; Rotundo \& Sackett 2002; Van Scotter \& Motowidlo 1996; Werner 1994). In general, these results show that task and citizenship behaviors explain similar amounts of variance in appraisal decisions, while in some cases OCBs explain substantially greater amounts of variance in appraisals than task behaviors do (Lowery \& Krilowicz 1994; MacKenzie et al. 1991, 1993).

Various factors have been argued to moderate the relationship between citizenship behaviors and performance appraisals. For example, MacKenzie et al. (1999) proposed that OCBs would take on greater importance for positions higher in an organizational hierarchy. Their results demonstrated that citizenship behaviors were more important to the appraisals of sales managers than they were to the appraisals of salespeople. Heilman and Chen (2005) argued that ratee gender would moderate the relationship between OCB and appraisals. They noted that citizenship behaviors are very closely associated with female gender roles and that women are generally expected, as a function of their gender, to be more helpful, loyal, cooperative, and so forth. Heilman and Chen's (2005) results demonstrated that ratee gender did indeed moderate the 
relationship between OCB and appraisals. In their study, women who demonstrated OCB on the job received less credit for doing so than men did, while women who failed to demonstrate OCB were penalized more harshly than men were.

In a similar fashion, it can be argued that the level of public service motivation a rater possesses will moderate the relationship between OCB and performance appraisals. Identifying a relationship between PSM and OCB has been done in one other study of which the authors are aware. In examining Korean public employees, Kim (2006) found that those with higher PSM exhibited increased performance of OCB. Kim did not, however, examine PSM across public and private sectors. Nor did the findings two sectors, nor did they engage consequences of PSM.

Public service motivation refers to a desire to serve the public good through loyalty to the government and public institutions, commitment to social justice, and compassion. In many ways OCB can be viewed as a behavioral manifestation of PSM, in a fashion very similar to that argued by Whiting et al. (2008) that organizational loyalty is a behavioral manifestation of commitment to the organization. As such, PSM as a work motivation or employee attitude may be manifested in behavioral form as altruism, helping, or loyalty. As Heilman and Chen (2005) argued regarding gender-determined expectations for women, it can be likewise argued that the prototypical role definition of a public servant will create the expectation that such individuals should be more helping, loyal, and cooperative, simply as a function of their role. As a result, those who perform OCB in public service settings may receive less credit for doing so (and greater penalty for failing to do so) than those who perform this behavior in private for-profit organizations.

\section{HYPOTHESES}

Research suggests that individuals who are high in public service motivation should be attracted to, selected into, and remain with organizations that primarily serve public interests. PSM theorists have raised (Schneider et al. 1995) and explored (Wright \& Christensen 2007) the attraction-selection-attrition mechanism as a foundation supporting those who have found that public organizations possess a higher level of PSM among employees than private organizations (Crewson 1997; Frank \& Lewis 2004; Posner \& Schmidt 1996). No studies were found that extended the reasoning and findings directly to this study's sample population-MPA and MBA students. One study did report higher mean PSM among undergraduates with public service majors than among undergraduate business majors (Karl \& Peat 2004, 267). These authors reasoned that the same selection and adaptation processes at work in occupational 
groups also apply to students selecting and remaining in sector-specific educational programs. By extension it can be intuited that students pursuing degrees that are primarily designed to lead to careers in public management (MPA programs) would demonstrate higher levels of PSM than students pursuing degrees leading to careers primarily in the management of private and for-profit organizations (MBA programs).

Hypothesis 1: MPA students will, on average, have higher PSM scores than MBA students.

As discussed previously, the prototypical role of a public servant may involve expectations of a high level of citizenship behavior in an organization. If MPA students are high in PSM, then they should view the performance of OCB as an expected part of the role of a public servant. As a result, in supervisory roles they should give less weight to these behaviors in making their appraisal decisions than MBA students would. Stated more generally, those with higher PSM will give less credit to employees who perform citizenship behaviors than those with lower PSM. Similarly, respondents with higher PSM will penalize the failure to perform citizenship behaviors more harshly than their counterparts with lower PSM.

Hypothesis 2: The relationship between OCB and performance appraisals will be moderated by PSM level. Respondents with high PSM will give less credit for OCB performance than respondents with low PSM.

\section{METHOD}

\section{Participants}

The primary participants in this study were fifty-five master's degree students at a large, southeastern university in the United States. In exchange for their participation, subjects were entered into a drawing for several iTunes gift certificates. Thirty-four students were enrolled in an MBA program offered through the business school, and twenty-one were enrolled in an MPA program. Fifty-eight percent of the participants were female, and the average participant age was thirty-one. Of the participants, 76 percent reported that they were employed full-time in addition to being students. The average reported length of full-time employment was 10 years, with 3.8 years in supervisory positions. Fifty-three percent of respondents either currently or previously had the responsibility to provide formal performance appraisals to subordinates at 
work. Thus, while technically a student sample, the majority of students had considerable working and managerial experience.

\section{Procedure}

This study utilized a mixed experimental design with three within-subjects factors (task, helping, and loyalty), each manipulated at two levels (high and low performance), and multiple between-subjects factors measuring facets of PSM, manipulated at six discrete levels pursuant to a seven-point Likert scale. These factors included attraction to policymaking, commitment to public interest, compassion, and self-sacrifice using indicator variables identified by Perry (1996).

Following a procedure that was similar to Werner (1994) and Whiting et al. (2008), subjects were presented with short vignettes describing the job behaviors of eight administrative assistants. The vignettes described critical incidents of performance for the dimensions of task, helping, and loyalty behaviors that were ostensibly written by a manager keeping a diary of observed employee behaviors. The citizenship behaviors of helping and loyalty were manipulated to reflect two levels of performance, high and low. Task behavior was also manipulated to reflect two levels of performance, high and low.

The study used the same critical incidents as those employed by Whiting et al. (2008), which have been demonstrated to faithfully manipulate the constructs of interest: task, helping, and loyalty behavior. These incidents were slightly altered, however, to be consistent with organizational settings most familiar to each type of student. Subjects who were MBA students were presented with vignettes describing the job behaviors of secretaries working in the finance department of a fictional pharmaceutical company. Before reading the vignettes, subjects were provided with a brief description of the company, its mission, the functions of the finance department, and a short job description of the secretary position. MPA students, on the other hand, were presented with vignettes describing the behaviors of secretaries working in the budget department of a city government. The vignettes were preceded by a short description of the city, the functions of the budget department, and the job description of the secretary. Thus, the vignettes were identical in all respects (with the exception of changing terms such as "financial analysts" to "budget analysts" and "the company" to "the city" and so forth), though they ostensibly took place in different settings. The secretary job descriptions were also identical. Sample incidents of task, helping, and loyalty behavior read as follows:

- "Even though several financial analysts got their month-ending reports to Chris 
late, she was still able to integrate them and somehow got them to me on time anyway" (task behavior).

- "Chris had accumulated some time off by working lunches and staying late. She checked with me and the other secretaries about taking tomorrow off. When it appeared that tomorrow would be very busy, she changed her plans so the other secretaries wouldn't be penalized by her absence" (helping behavior).

- "Even when rumors were circulating about a major oversight the finance department supposedly made, I heard Chris telling her friends that she just couldn't believe the story was true, and that the department would be cleared of any wrongdoing in the end" (loyalty behavior).

\section{Measures}

Once participants had finished reviewing the vignettes, they completed a threeitem overall performance appraisal measure adapted from MacKenzie et al. (1991) for each of the eight secretaries. (At any time after reading the vignettes, respondents were able to open a separate computer window to review them.) A sample item read, "All things considered, this employee is outstanding." These items used a seven-point Likert scale, with 1 standing for "strongly disagree" and 7 for "strongly agree." The coefficient alpha of the repeated measurement items for each employee acceptably ranged between 0.81 and 0.98 .

Participants then completed a twenty-five-item measure of public service motivation based on Perry (1996). ${ }^{1}$ A sample item reads, "I feel people should give back to society more than they get from it." These items used a seven-point Likert scale, with 1 standing for "strongly disagree" and 7 for "strongly agree." The coefficient alphas for the variables indicating four PSM factors-policy-making, commitment to public interest, compassion, and self-sacrifice—were $0.69,0.84,0.76$, and 0.89 respectively.

\section{RESULTS}

Table 1 shows the mean public service motivation scores of both MPA and MBA students. As expected, MPA students reported higher levels of PSM than MBA students across all factors. Because some of the MPA students in the sample may have been exposed to the concept of public service motivation in an introductory course, presenting a threat that socialization might account for some of the differences in

1. The measure included 24 items from Perry's original 40 questions plus, "I am not afraid to go to bat for the rights of others even if it means I will be ridiculed." 
scores, the study also tested an independent sample at a major university in a neighboring state. While the second sample was nearly identical in work experience, age, and gender, it was possible to ascertain with some certainty that these respondents had not been formally exposed to the concept of public service motivation. The results of this second sample were similar, if not more striking (see table 2). Thus, results supported hypothesis 1 .

Table 1. Mean Public Service Motivation Scores

\begin{tabular}{l|c|c|c|c}
\hline \multicolumn{1}{c|}{ PSM factors } & & $\mathrm{N}$ & $\mathrm{M}$ & SD \\
\hline \multirow{2}{*}{ Attraction to policy making* $^{*}$} & MBA & 34 & 3.1 & 1.4 \\
\cline { 2 - 5 } & MPA & 21 & 3.7 & 1.0 \\
\hline \multirow{2}{*}{ Commitment to public interest $^{\star *}$} & MBA & 34 & 4.1 & 1.3 \\
\cline { 2 - 5 } & MPA & 21 & 5.2 & 1.0 \\
\hline \multirow{2}{*}{ Compassion $^{* *}$} & MBA & 34 & 4.1 & 1.0 \\
\cline { 2 - 5 } & MPA & 21 & 5.1 & 0.9 \\
\hline \multirow{2}{*}{ Self-sacrifice $^{* *}$} & MBA & 34 & 4.2 & 1.2 \\
\cline { 2 - 5 } & MPA & 21 & 5.2 & 0.8 \\
\hline
\end{tabular}

* Significant difference in means between the two groups at the 0.1 level $(t=-1.8,53 d f, p=0.07)$

${ }^{*}$ Significant difference in means between the two groups at the 0.01 level

Table 2. Mean Public Service Motivation Scores, Second Sample

\begin{tabular}{|c|c|c|c|c|}
\hline PSM factors & & $\mathrm{N}$ & M & SD \\
\hline \multirow{2}{*}{ Attraction to policy-making ${ }^{\star *}$} & MBA & 10 & 2.9 & 1.3 \\
\hline & MPA & 15 & 5.1 & 0.9 \\
\hline \multirow{2}{*}{ Commitment to public interest* ${ }^{\star \star}$} & MBA & 10 & 3.9 & 1.0 \\
\hline & MPA & 15 & 5.3 & 0.8 \\
\hline \multirow{2}{*}{ Compassion ${ }^{\star *}$} & MBA & 10 & 3.7 & 0.8 \\
\hline & MPA & 15 & 5.4 & 0.9 \\
\hline \multirow{2}{*}{ Self-sacrifice* } & MBA & 10 & 4.1 & 1.1 \\
\hline & MPA & 15 & 5.1 & 2.9 \\
\hline
\end{tabular}

* Significant difference in means between the two groups at the 0.1 level $(t=-2.7,23 d f, p=0.012)$

** Significant difference in means between the two groups at the 0.01 level

While the first hypothesis probes an aspect of PSM's existence, the second focuses on PSM's consequences. Of interest was whether PSM played an important role in a common organizational activity: performance appraisals. While there were some limi- 
tations in sample size - partially ameliorated by the fact that each respondent evaluated eight employees ${ }^{2}$ - a preliminary analysis of the research hypotheses is possible.

Using repeated measures ANOVA, the study found mixed support for its assumptions about the consequences of PSM. Beginning with the full sample, however, only one marginally significant relationship was found between the PSM constructs and how a respondent rated organizational citizenship or task behaviors. Unexpectedly, that relationship was between appraisal of task performance (a non-OCB behavior) and commitment to public interest. At this point the authors are unable to draw any conclusions about the existence of this relationship.

Since one of the criticisms commonly leveled at the practice of using "paper people" is its discontinuity with "real world" observations (see Whiting et al. 2008), this study sought to identify those respondents within the sample who had had real-world evaluation experience. The majority of respondents (twenty-nine) indicated they had responsibility for evaluating someone's performance at work either at the time of the study or in the past.

The sample was then restricted to those with current or past evaluation responsibilities and reanalyzed in terms of the second hypothesis. The results constitute an interesting pattern that lends some support for that hypothesis. Loyalty significantly interacted with each of the four PSM factors to predict performance appraisals. Helping also exhibited statistically significant interactions, with self-sacrifice and compassion at the 0.05 and 0.1 levels (and attraction to public policy nearly at the latter level). Notably, task behavior did not significantly interact with any of the PSM factors.

Table 3 provides the repeated measure's ANOVA results and partial $\eta 2$ (effect size) estimates when attraction to public policy was used as the between factor to assess how respondents rated the eight administrative assistants. As is evident in table 3, task and organizational citizenship behaviors had significant main effects on performance appraisals $(F$-values $\geq 62$, all $p$-values $<0.01)$. Further, the effect size estimates $(\eta 2)$ indicate that task and helping are nearly equally important $(0.82)$ in the appraisal decisions, followed by loyalty (0.74). In other words, the findings indicate, as might be expected, that higher levels of task behavior and OCB are associated with higher performance appraisals.

2. While the full sample size was in essence $55 \times 8$ secretaries because of the repeated measure, the potential exists for sample limitations inasmuch as error terms may be correlated casewise (for example, a respondent's appraisal of administrative assistant \#1 may be related to the same respondent's appraisal of administrative assistant \#2). However, the authors did not find consistent evidence of this in the sample. Where there was evidence of a linear relationship, the strength of the relationship was very weak. 
Looking at how PSM interacted with these main effects, table 3 provides evidence that attraction to public policy significantly interacts with the OCB loyalty (F-value = 3.01, p-value $=0.03)$. A fairly sizeable effect size $(0.45)$ was also noted. Loyalty also interacted with the other PSM factors in a fairly substantial manner given the estimated effect sizes:

Table 3. ANOVA Appraisal Results: Attraction to Policy-Making

\begin{tabular}{l|r|r|r|c}
\hline \multicolumn{1}{c|}{ Factor } & \multicolumn{2}{|c|}{ F value } & Sig. & Partial $\eta 2$ \\
\hline Task & 96.83 & $(1,22)$ & 0.00 & 0.82 \\
Task * attraction & 1.11 & $(6,22)$ & 0.39 & 0.23 \\
Helping & 97.29 & $(1,22)$ & 0.00 & 0.82 \\
Helping * attraction & 1.95 & $(6,22)$ & 0.12 & 0.35 \\
Loyalty & 62.20 & $(1,22)$ & 0.00 & 0.74 \\
Loyalty * attraction & 3.01 & $(6,22)$ & 0.03 & 0.45 \\
Task * helping & 4.18 & $(1,22)$ & 0.05 & 0.16 \\
Task * helping * attraction & 1.90 & $(6,22)$ & 0.13 & 0.34 \\
Task * loyalty & 3.82 & $(1,22)$ & 0.06 & 0.15 \\
Task * loyalty * attraction & 1.29 & $(6,22)$ & 0.30 & 0.26 \\
Helping * loyalty & 0.90 & $(1,22)$ & 0.35 & 0.04 \\
Helping * loyalty * attraction & 1.47 & $(6,22)$ & 0.24 & 0.29 \\
Task * helping * loyalty & 0.00 & $(1,22)$ & 0.98 & 0.00 \\
Task * helping * loyalty * attraction & 1.87 & $(6,22)$ & 0.13 & 0.34 \\
\hline
\end{tabular}

Table 4. ANOVA Appraisal Results: Commitment to Public Interest

\begin{tabular}{l|r|r|r|c}
\hline \multicolumn{1}{c|}{ Factor } & \multicolumn{2}{|c|}{$\begin{array}{c}\text { F value } \\
\text { (hypothesis, error df) }\end{array}$} & Sig. & Partial $\eta 2$ \\
\hline Task & 101.26 & $(1,22)$ & 0.00 & 0.82 \\
Task * commitment & 1.35 & $(6,22)$ & 0.28 & 0.27 \\
Helping & 96.19 & $(1,22)$ & 0.00 & 0.81 \\
Helping * commitment & 1.48 & $(6,22)$ & 0.23 & 0.29 \\
Loyalty & 94.66 & $(1,22)$ & 0.00 & 0.81 \\
Loyalty * commitment & 3.27 & $(6,22)$ & 0.02 & 0.47 \\
Task * helping & 0.88 & $(1,22)$ & 0.36 & 0.04 \\
Task * helping * commitment & 0.39 & $(6,22)$ & 0.88 & 0.10 \\
Task * loyalty & 3.99 & $(1,22)$ & 0.06 & 0.15 \\
Task * loyalty * commitment & 1.03 & $(6,22)$ & 0.43 & 0.22 \\
Helping * loyalty & 6.00 & $(1,22)$ & 0.02 & 0.21 \\
Helping * loyalty * commitment & 0.93 & $(6,22)$ & 0.49 & 0.20 \\
Task * helping * loyalty & 1.70 & $(1,22)$ & 0.21 & 0.07 \\
Task * helping * loyalty * commitment & 0.41 & $(6,22)$ & 0.87 & 0.10 \\
\hline
\end{tabular}


Table 5. ANOVA Appraisal Results: Compassion

\begin{tabular}{l|r|r|r|c}
\hline \multicolumn{1}{c|}{ Factor } & \multicolumn{2}{|c|}{ F value } & Sig. & Partial $\eta 2$ \\
& \multicolumn{2}{|c|}{ (hypothesis, error df) } & & \\
\hline Task & 92.60 & $(1,23)$ & 0.00 & 0.80 \\
Task * compassion & 1.17 & $(5,23)$ & 0.36 & 0.20 \\
Helping & 103.49 & $(1,23)$ & 0.00 & 0.82 \\
Helping * compassion & 2.54 & $(5,23)$ & 0.06 & 0.36 \\
Loyalty & 105.58 & $(1,23)$ & 0.00 & 0.82 \\
Loyalty * compassion & 6.10 & $(5,23)$ & 0.00 & 0.57 \\
Task * helping & 0.22 & $(1,23)$ & 0.65 & 0.01 \\
Task * helping * compassion & 0.45 & $(5,23)$ & 0.81 & 0.09 \\
Task * loyalty & 3.39 & $(1,23)$ & 0.08 & 0.13 \\
Task * loyalty * compassion & 0.93 & $(5,23)$ & 0.48 & 0.17 \\
Helping * loyalty & 3.98 & $(1,23)$ & 0.06 & 0.15 \\
Helping * loyalty * compassion & 0.85 & $(5,23)$ & 0.53 & 0.16 \\
Task * helping * loyalty & 4.27 & $(1,23)$ & 0.05 & 0.16 \\
Task * helping * loyalty * compassion & 1.12 & $(5,23)$ & 0.38 & 0.20 \\
\hline
\end{tabular}

Table 6. ANOVA Appraisal Results: Self-Sacrifice

\begin{tabular}{|c|c|c|c|c|}
\hline \multirow[t]{2}{*}{ Factor } & \multicolumn{2}{|c|}{$\begin{array}{c}\text { F value } \\
\text { (hypothesis, error df) }\end{array}$} & \multirow{2}{*}{$\begin{array}{l}\text { Sig. } \\
0.00\end{array}$} & \multirow{2}{*}{$\begin{array}{c}\text { Partial } \eta 2 \\
0.83\end{array}$} \\
\hline & 110.25 & $(1,23)$ & & \\
\hline Task * sacrifice & 0.68 & $(5,23)$ & 0.64 & 0.13 \\
\hline Helping & 137.81 & $(1,23)$ & 0.00 & 0.86 \\
\hline Helping * sacrifice & 2.62 & $(5,23)$ & 0.05 & 0.36 \\
\hline Loyalty & 119.02 & $(1,23)$ & 0.00 & 0.84 \\
\hline Loyalty * sacrifice & 4.89 & $(5,23)$ & 0.00 & 0.52 \\
\hline Task * helping & 1.49 & $(1,23)$ & 0.23 & 0.06 \\
\hline Task * helping * sacrifice & 0.37 & $(5,23)$ & 0.87 & 0.07 \\
\hline Task * loyalty & 3.70 & $(1,23)$ & 0.07 & 0.14 \\
\hline Task * loyalty * sacrifice & 1.03 & $(5,23)$ & 0.42 & 0.18 \\
\hline Helping * loyalty & 4.11 & $(1,23)$ & 0.05 & 0.15 \\
\hline Helping * loyalty * sacrifice & 1.09 & $(5,23)$ & 0.40 & 0.19 \\
\hline Task * helping * loyalty & 2.19 & $(1,23)$ & 0.15 & 0.09 \\
\hline Task * helping * loyalty * sacrifice & 0.83 & $(5,23)$ & 0.54 & 0.15 \\
\hline
\end{tabular}

Table 7. PSM/OCB Interaction Effects

\begin{tabular}{c|c||c|c}
\hline PSM: Attraction & $\begin{array}{c}\text { High loyalty } \\
\text { mean appraisal }\end{array}$ & PSM: Attraction & $\begin{array}{c}\text { High loyalty } \\
\text { mean appraisal }\end{array}$ \\
\hline 1 & 4.81 & 5 & 4.25 \\
2 & 4.36 & 6 & 3.50 \\
\hline
\end{tabular}


- Commitment to public interest $(\mathrm{F}$-value $=3.01$, p-value $=0.02, \eta 2=47-$ see table 4)

- Compassion $(\mathrm{F}$-value $=6.10, \mathrm{p}$-value $=0.00, \eta 2=0.57$-see table 5$)$

- Self-sacrifice $($ F-value $=4.89, \mathrm{p}$-value $=0.00, \eta 2=0.52$ - see table 6$)$

Additionally, helping significantly interacted with the PSM factors of compassion $(\mathrm{F}$-value $=2.54, \mathrm{p}$-value $=0.06, \eta 2=0.36)$ and self-sacrifice $(\mathrm{F}$-value $=2.62 \mathrm{p}$-value $=0.05, \eta 2=0.36$ )-see tables 5 and 6 .

To understand these interactions' effects, the mean values of OCB and PSM were consulted to determine the direction of these interactions. In general, the means indicate that the relationship functions much as hypothesis 2 suggests. Table 7 presents the means associated with the interaction between loyalty and attraction to public policy. The higher individuals scored on attraction to public policy, the less weight they place on loyalty behavior in making their appraisal decisions. This supports the notion that managers who have high levels of PSM themselves view the performance of OCB on the part of subordinates as an expected part of a public servant's role and give little credit for it in performance appraisals.

\section{CONCLUSION}

The results of this research provide solid support for the hypotheses that MPA students possess higher levels of PSM than their MBA counterparts, and that these differences will impact the manner in which these students make performance appraisal decisions.

Even in relatively small samples of MBA and MPA students, rather strong evidence was found that MPA students have greater public service motivation than MBA students. This finding alone represents an important contribution to the public administration literature. As mentioned previously, PSM research has been somewhat inconsistent in confirming the fundamental hypotheses of the theory (Wright 2001). However, these results, while limited by sample size, do seem to indicate that an attractionselection-attrition mechanism is operating to bring those with higher public service motivations into public administration programs.

While sample size limits this study's ability to make the kinds of inferences the authors believe are present relative to hypothesis 2, a consistent and theoretically grounded pattern was found in support of the notion that the differences in public service motivation impact organizational outcomes-here, performance appraisal decisions-in the manner hypothesized. High-PSM raters did indeed give less credit to 
employees who showed high levels of OCB than did raters exhibiting lower levels of PSM. Thus, it could be the case that sector type will impact the manner in which various job behaviors are weighted in appraisal decisions. This has potentially important implications for the performance appraisal literature, as the type of organization might be an important boundary variable in determining the weight raters will apply to citizenship behaviors in making their appraisal decisions.

Clearly, more research is needed to confirm and extend these findings. Specifically, future research will need to investigate this phenomenon in real organizations, potentially using both experimental and more traditional survey-oriented research methods. Notwithstanding the limitations of this work, initial support for its central hypotheses was demonstrated. Public service motivation significantly impacted the manner in which raters approached performance appraisals. This seems to indicate that public service motivation is an important factor to consider in the management of public sector organizations, which might influence processes as basic as the provision of performance appraisals.

\section{REFERENCES}

Allen, T. D., \& M. C. Rush. (1998). The effects of organizational citizenship behavior on performance judgments: A field study and a laboratory experiment. Journal of Applied Psychology, 83(2): 247-60.

Bernardin, H. J., \& M. R. Buckley. (1981). Strategies in rater training. Academy of Management Review, 6: 205-12.

Borman, W. C., \& S. J. Motowidlo. (1993). Expanding the criterion domain to include elements of contextual performance. In N. Schmitt and W. C. Borman (Ed.), Personnel selection in organizations (pp. 77-98). San Francisco: Jossey-Bass.

Borman, W. C., L. A. White, \& D. W. Dorsey. (1995). Effects of ratee task performance and interpersonal factors on supervisor and peer performance ratings. Journal of Applied Psychology, 80(1): 168-77.

Cardy, R. L., \& G. H. Dobbins. (1994). Performance appraisal: Alternative perspectives. Cincinnati, OH: South-Western Publishing Co.

Crewson, P. E. (1997). Public-service motivation: Building empirical evidence of incidence. Journal of Public Administration Research \& Theory (Transaction), 7(4): 499.

DeNisi, A. S. (1996). Cognitive approach to performance appraisal: A program of research. New York: Routledge.

Dunlop, P. D., \& K. Lee. (2004). Workplace deviance, organizational citizenship 
behavior, and business unit performance: The bad apples do spoil the whole barrel. Journal of Organizational Behavior, 25: 67-80.

Feldman, J. M. (1994). On the synergy between theory and application: Social cognition and performance appraisal. In R. S. J. Wyer and T. K. Srull (Eds.), Handbook of social cognition (vol. 2, pp. 339-97). Hillsdale, NJ: Lawrence Erlbaum Associates.

Frank, S. A., \& G. B. Lewis. (2004). Government employees: Working hard or hardly working? American Review of Public Administration, 34(1): 36-51.

Heilman, M. E., \& J. J. Chen. (2005). Same behavior, different consequences: Reactions to men's and women's altruistic citizenship behavior. Journal of Applied Psychology, 90(3): 431-41.

Karl, K. A., \& B. Peat. (2004). A match made in heaven or a square peg in a round hole? How public service educators can help students assess person-environment fit. Journal of Public Affairs Education, 10(4): 265-77.

Kim, S. (2006). Public service motivation and organizational citizenship behavior in Korea. International Journal of Manpower, 27(7-8): 722-40.

Koys, D. J. (2001). The effects of employee satisfaction, organizational citizenship behavior, and turnover on organizational effectiveness: A unit-level, longitudinal study. Personnel Psychology, 54(1): 101-14.

Lowery, C. M., \& T. J. Krilowicz. (1994). Relationships among nontask behaviors, rated performance, and objective performance measures. Psychological Reports, 74: 571-78.

MacKenzie, S. B., P. M. Podsakoff, \& R. Fetter. (1991). Organizational citizenship behavior and objective productivity as determinants of managerial evaluations of salespersons' performance. Organizational Behavior and Human Decision Processes, 50:123-50.

. (1993). The impact of organizational citizenship behavior on evaluations of salesperson performance. Journal of Marketing, 57: 70-80.

. (1999). Do citizenship behaviors matter more for managers than for salespeople? Journal of the Academy of Marketing Science, 27(4): 396-410.

Motowidlo, S. J., \& J. R. Van Scotter. (1994). Evidence that task performance should be distinguished from contextual performance. Journal of Applied Psychology, 79(4): 475-80.

Organ, D. W. (1988). Organizational citizenship behavior: The good soldier syndrome. Lexington, MA: Lexington Books.

Orr, J. M., P. R. Sackett, \& M. Mercer. (1989). The role of prescribed and nonprescribed behaviors in estimating the dollar value of performance. Journal of Applied Psychology, 74: 34-40. 
Perry, J. L. (1996). Measuring public service motivation: An assessment of construct reliability and validity. Journal of Public Administration Research \& Theory (Transaction), 6(1): 5.

Perry, J. L., \& L. R. Wise. (1990). The motivational bases of public service. Public Administration Review, 50(3): 367-73.

Podsakoff, P. M., \& S. B. MacKenzie. (1994). Organizational citizenship behavior and the quantity and quality of work group performance. Journal of Marketing Research, 31: 351-63.

Podsakoff, P. M., M. Ahearne, \& S. B. MacKenzie. (1997). Organizational citizenship behavior and the quantity and quality of work group performance. Journal of Applied Psychology, 82(2): 262-70.

Podsakoff, P. M., S. B. MacKenzie, J. B. Paine, \& D. G. Bachrach. (2000). Organizational citizenship behaviors: A critical review of the theoretical and empirical literature and suggestions for future research. Journal of Management, 26(3): 513-63.

Posner, B. Z., \& W. H. Schmidt. (1996). The values of business and federal government executives: More different than alike. Public Personnel Management, 25(3): 277-89.

Rotundo, M., \& P. R. Sackett. (2002). The relative importance of task, citizenship, and counterproductive performance to global ratings of job performance: A policycapturing approach. Journal of Applied Psychology, 87(1): 66-80.

Schneider, B., H. W. Goldstein, \& D. B. Smith. (1995). The ASA framework: An update. Personnel Psychology, 48: 747-73.

Van Scotter, J. R., \& S. J. Motowidlo. (1996). Interpersonal facilitation and job dedication as separate facets of contextual performance. Journal of Applied Psychology, 81(5): 525-31.

Walz, S. M., \& B. P. Niehoff. (2000). Organizational citizenship behaviors: Their relationship to organizational effectiveness. Journal of Hospitality \& Tourism Research, 24: 301-319.

Werner, J. M. (1994). Dimensions that make a difference: Examining the impact of inrole and extra-role behaviors in supervisory ratings. Journal of Applied Psychology, 79(1): 98-107.

Whiting, S. W., P. M. Podsakoff, \& J. R. Pierce. (2008). The effects of task performance, helping, voice, and organizational loyalty on performance appraisal ratings. Journal of Applied Psychology, 93(1): 125-39.

Williams, L. J., \& S. E. Anderson. (1991). Job satisfaction and organizational commitment as predictors of organizational citizenship and in-role behaviors. Journal of Management, 17(3): 601-17. 
Wright, B. E. (2001). Public-sector work motivation: A review of the current literature and a revised conceptual model. Journal of Public Administration Research and Theory, 11(4): 559-86.

. (2007). Methodological challenges associated with public service motivation research. In James L. Perry and Annie Hondeghem (Eds.), Motivation in public management (pp. 80-98). Oxford University Press, USA.

Wright, B. E., \& R. K. Christensen. (2007). Public service motivation: A longitudinal analysis of the job attraction-selection-attrition model. Paper presented at the 9th Public Management Research Conference. University of Arizona, Tucson, Arizona. 